\title{
Penerapan Historical Thinking dalam Meningkatkan Berpikir Kritis Siswa
}

\author{
Annisa \\ Email: $1810111120017 @$ mhs.ulm.ac.id \\ Program Studi Pendidikan Sejarah Fakultas dan Ilmu Pendidikan \\ Universitas Lambung Mangkurat \\ Banjarmasin
}

\begin{abstract}
Abstrak
Artikel ini memuat tentang penerapan berpikir historis dapat meningkatkan berpikir kritis siswa. Pembelajaran sejarah bukan hanya renteran peristiwa, namun dari sejatah kita mendapatkan wacana intelektual yang kritis. Namun, pada praktiknya peserta didik tidak dapat berpikir kritis, karena sekolah belum menerapkan cara berpikir historis. Untuk meningkatkan cara berpikir historis, tentu saja banyak cara dengan menggunakan metode, model, dan strategi dalam pembelajaran sejarah. Dengan begitu peserta didik dapat memicu kemampuan berpikir tingkat tinggi peserta didik, mendorong munculnya kreativitas dan terbiasa terhadap perbedaan perspektif
\end{abstract}

Kata Kunci: Historical Thinking, Berpikir Kritis

\section{Pendahuluan}

Menurut Taufik Abdullah (dalam Anis, 2015:58), pembelajaran sejarah bukan rentetan yang kering dan particular tetapi sebuah wacana intelektual yang kritis dan rasional. Pembelajaran sejarah harus dilalui melalui dua tahapan, yaitu (1) memupuk kesadaran sosial dan keakraban, (2) memperkenalkan makna dimensi waktu dalam dinamika kehidupan kepada siswa dan rasa hayat sejarah.

Namun pada kenyataannya Sejarah yang diajarkan kepada peserta didik cenderung menjadi sebuah warisan yang dikenang dan kemudian dihapalkan (Sarbaini et.al., 2019 dalam Anis, \& Wiyanarti, 2021: 2). Hal ini menunjukkan bahwa pembelajaran sejarah bagi peserta hanya formalitas dalam belajar. Seharusnya, melalui pembelajaran sejarah siswa memiliki kesadaran akan sejarah.

Terlebih dalam pembelajaran Sejarah, di mana setiap peristiwa cenderung bersifat multidimensional sehingga memungkinkan banyak jawab untuk satu persoalan saja. Sisi 
positifnya, hal ini dapat memicu kemampuan berpikir tingkat tinggi peserta didik, mendorong munculnya kreativitas dan terbiasa terhadap perbedaan perspektif (Anis, Sriwati, Mardiani, 2020: 178)

Diketahui bahwa tujuan sejarah itu untuk mengembangkan pemahaman diri sendiri, sehingga bangsa kita tahu arti menjadi bangsa Indonesia, tanpa sejarah juga generasi muda tidak tahu bagaimana para pendahulu secara gigih memperjuangkan kemerdekaan, tanpa sejarah para politikus generasi baru tidak pernah tahu struktur negara Pancasilais yang menjadi ideologi negara (Anis, 2015: 59).

Untuk meningkatkan berpikir kritis peserta didik, dibutuhkan penerapan model pembelajaran sejarah. Kemampuan berpikir kritis dan menerakan model pembelajaran dibutuhkan sebagai prasyarat untuk memenuhi pembelajaran sejarah kritis (Anis, Putri, Arisanty, \& Rinjani, 2019 dalam Anis, \& Wiyanarti, 2021: 1).

Pembelajaran Sejarah mengacu pada mencari, menemukan, memverifikasi, maka diperluakan kemampuan berpikir historis bagi guru dan peserta didik. Melalui kemampuan berpikir historis, maka output pembelajaran sejarah sosok siswa yang memiliki kemampuan untuk memperoleh nilai-nilai dari sejarah (Anis, 2015: 59).

Menurut Murni (dalam Nurjanah, 2020: 94), keterampilan berpikir sejarah ini sangat penting karenadapat meningkatkan kemamupan berpikir kritis peserta didik. Peserta didik belajar dari sejarah untuk meningkatkan keterampilan berpikir kritis. Peserta didik dapat mengajukan pertanyaan kritis dan dapat juga menjawa argument dengan menyertakan bukti yang faktual. Sehingga kemepuan berpikir kritis ini sangat penting karena termasuk salah satu keterampilan yang harus dimilik peserta didik pada era ini.

Artikel ini akan membahsas tentang penerapan Historical Thinking yang dapat meningkatkan cara berpikir kritis peserta didik dengan cara menerapkan model pembelajaran.

\section{Historical Thinking dan Penerapannya}

Pendidikan sejarah sebagai salah satu cabang pendidikan ilmu sosial, menyediakan berbagai pengalaman belajaruntuk memahami konsep dan keterampilan berpikir historis. Tuntutan dalam rumusan salah satu Kompetensi dasar dalam standar isi kurikulim nasionla untuk Sekolah Menengah Atas/ Madrasah Aliyah (SMA/MA) adalah agar peserta didik dapat mengembangkan kemampuan untuk memahami dan menerapkan prinsip dasar inquiry. Kemampuan berinkuiri merupakan aplikasi dari keterampilan berpikir historis dalam mata pelajaran sejarah. Dalam setiap proses berpikir historis selalu melibatkan proses berfikir. 
Dengan demikian, keterampilan berpikir historis juga dapat mendorong berkembangnya kemampuan berpikir kritis dan kreatif pada diri peserta didid (Ofianto, 2017: 165)

Historical Thinking atau keterampilan berpikir historis adalah kemampuan agar peserta didik dapat membedakan waktu lampau, masa kini, dan masa yang akan mendatang, melihat dan mengevaluasi evidensi, dapat membandingkan dan menganalisi cerita sejarah, ilustrasi, dan catatan dari masa lalu, menginterpretasikan catatan sejarah, dan membangun suatu cerita berdasarka pemahamannya (Isjoni, 2007 dalan Nurjanah, 2020: 94)

Keterampilan berpikir sejarah adalah keterampilan yang harus dimiliki peserta didik. Hali ini dibutuhkan dalam menggali materi pembelajran sejarah, pengembangan keterampilan berpikir historis dalam pembelajaran ini dapat diharapkan membantu peserta didik lebih kritis dalam menjawab berbagai permasalahan dalam proses berbagai permasalahan dalam proses pembelajaran (Hudaidah: 6)

Berpikir historis pada dasarnya adalah sebuah aktivitas berpikir seseorang layaknya sejarawan yang sedang mengkritik sumber berbentuk dokumen (Anis, 2015: 59). Membangun berpikir historis memerlukan hubungan anatar teori-teori yang ada di dalam ilmu sejarah dengan landasan fillosofis dan teori dalam pendidikan sejarah (Anis, 2015: 60).

Konsep berpikir historis memiliki dua konsep. Konsep pertama, menurut Zed (2018: 56) terdapat lima komponen dasar berpikir sejarah, komponen ini disebut dengan "The Five C' $s$ ", karena semuannya berawal dari huruf "C", yaitu $\mathrm{C} 1$ = Change over time, perubahan selalu berlangsung dalam waktu ;C2 = Causlity, konsep "sebab" dalam sejarah mengacu pada Tindakan atau kejadian yang dapat menyebabkan terjadinya Tindakan atau peristiwa lain, hasil dari tindakan atau kejadian itu disebut dengan akibat ; $\mathrm{C} 3=$ Context, proses intelektual dalam kerangka mengerti sejarah; $\mathrm{C} 4$ = Complexity, sejarah bersifat kompleks, rumit yang tidak mungkin manusia dapat menangkap totalitas kejadian kecuali terbatas pada aspek-aspek tertentu ;C5 = Contigency, sejarah bersifat kemungkinan atau ada unsur tak terduga adalah masuk akal.

Konsep kedua adalah The Big Six, dalam berpikir sejarah ini merupaka konsep lanjutan dari The Five C's. keenam konsep berpikir sejarah tersebut adalah (1) Signifikasi Sejarah, sejarah adalah apa yang dianggap penting dan menonjol serta membawa perubahan penting, baik pada masanya maupun jangka panjang; (2) bukti, sejarah adalah studi tentang fakta-fakta, fakta ini bergantung pada data (bukti); (3) yang tetap dan yang berubah, sejarah berkenaan dengan perubahan tetapi di samping itu ada juga unsur yang tidak berubah; (4) sebab dan konsekuensi, peristiwa historis tidak pernah berdiri sendiri dan saling berkaitan satu sama lainnya; (5) perspektif sejarah, mengerti sejarah berdasarkan cara piker sejarah (diakronik); (6) 
dimensi etis, sejarah seperti halnya dengan prinsip keilmuan apa pun memiliki tanggung jawab etis.

Instrumen berpikir historis yang dianggap sanga penting ini ternyata masih belum terstandari dengan baik, hal ini membuat para pendidik masih berupaya dengan meneliti instrument-instrumen yang dibutuhkan dalam pembelajaran sejarah. Instrument penilaian berpikir historis yang mengacu pada pencapaian dimensi kognitif siswa yaitu, faktual, konseptual, prosedural, dan metakognitif (Anis, et.al., 2020: 7904)

Dari penelitian yang dilakukan Putro (2012: 215) Model inkuiri dalam pembelajaran sejarah sesuai tuntutan reformasi dan dapat digunakan untuk meningkatkan kesadaran sejarah. Hal ini terlihat dari meningkatnya kemampuan berpikir ke sejarahan (historical thinking), dan ke mampuan memecahkan permasalahan sejarah secara ilmiah. Temuan penelitian menunjukkan bahwa siswa mampu menjelaskan dan menganalisis perubah an dan kontinuitas, nasionalisme, guna sejarah, dan perspektif tentang waktu.

\section{Upaya Meningkatkan Berpikir Kritis}

Berpikir Kritis merupakan tujuan ideal dalam Pendidikan karena mempersiapkan peserta didik untuk kehidupan yang akan datang. Mempersiapkan peserta didik untuk kehidupan yang akan datang bekan berate memberikan kepada mereka sesutu yang sudah disiapkan tetapi mengikutsertakan peserta didik didalam pemenuhan perkembangan dirinya sendiri dan arah dari perkembangannya sendiri (Self-direction) (Rohani, \& Sumantri, 2020: 53).

Tujuan ideal didalam pendidikan modern terutama pembelajaa=ran sejarah memerlukan kemampuan berfikir kritis, baik dalam memahami fakta sejarah ataupun saat pengambilan sikap ketika menghadapi segala perkembangan yang terjadi seahri-hari. Berpikir kritis tidak hanya diperlukan untuk memahami fakta sejarah saja, namun juga saat pengambilan sikap yaitu ketika peserta didik dapat menjadikaan pengalaman di masa lalu sebagai bahan pembelajaran dalam menyelesaikan masalah yang sedang dihadapi di masa sekarang sehingga pesrta didik mampu menjadi bijaksan dala pengambilan keputusan.

Keterampilan berpikir kritis adalah pengaturan diri dalam memutuskan sesuatu yang menghasilkan interpretasi, analisis, evaluasi, dan inferensi, atau pertimbangan kontekstual yang menjadi dasar dibuatnya keputusan (facione, 2010 dalan Nurjanah, 2020: 100).

Belajar sejarah bukan hanya sekedar mengahafal fakta-fakta sejarah, tetapi cenderung melihat hubungan antara apa yang terjadi di masal lampau dengan kondisi saat ini yang kemudian peserta didik dapat lebih bijaksana dalam menghadapinya (Kamarga, 2017: 2) 
Namun, pada praktiknya proses pembelajaran sejarah di sekolah, kemampuan berpikir kritis pesrta didik terhadap perisitiwa dan fakta sejarah yang dikaitkan dengan keadaan masyarakat sekarang kurang dikembangkan dengan baik.

Pencapaian keterampilan tersebut dapat dicapai dengan penerapan metode pembelajaran yang sesuai dari sisi penguasaan materi dan keterampilan. Kemampuan berpikir kritis siswa dibangun melalui pembelajaran yang menerapkan taksonomi pembelajaran sebagaimana disampaikan oleh Benyamin Bloom tahun 1956 membagi tujuan pendidikan menjadi tiga ranah yaitu ranah kognitif, afektif, dan psikomotor. Taksonomi pembelajaran dikelompokan dalam dimensi pengetahuan dan dimensi proses kognitif. Dimensi proses pengetahuan terdiri empat bagian yaitu faktual, konseptual, prosedural, dan metakognitif (Nurjanah, 2020: 100).

Dalam penelitian yang dilakukan Rohani dan Sumantri (2020: 59), kemampuan berpikir kritis peserta didik dapat ditingkatkan dengan menggunakan strategi Go To Your Post dalam pembelajaran sejarah. Peningkatan tersebut nampak disetiap siklus yang telah dilakukan. Hasil tersebut menunjukan bahwa siswa kelas XII IPS 1 memiliki kemampuan berpikir kritis yang sudah sangat baik selama penerapan strategi Go To Your Post dalam pembelajaran sejarah. Hal ini terbukti dari siswa mampu untuk mengumpulkan informasi, menganalisis informasi, memberikan penjelasan sederhana, dan menyimpulkan. Selain itu, dalam pelaksanaan penerapan strategi Go To Your Post sudah dapat mencari dan menemukan pos, mendiskusikan masalah, menyelesaikan masalah, dan mengevaluasi

\section{Kesimpulan}

Pembelajaran Sejarah pada saat ini bukan hanya membicarakan tentang fakta-fakta sejarah, tetapi peserta didik ditantang untuk berpikir kritis dalam mehadapi suatu fenomena sejarah.

Namun pada praktiknya, proses pembelajaran sejarah di sekolah, kemampuan berpikir kritis pesrta didik terhadap perisitiwa dan fakta sejarah yang dikaitkan dengan keadaan masyarakat sekarang kurang dikembangkan dengan baik.

Historical Thinking atau keterampilan berpikir historis adalah suatu kemampuan peserta didik yang dapat membedakan waktu lampau, masa kini, dan masa yang akan mendatang, melihat dan mengevaluasi evidensi, dapat membandingkan dan menganalisi cerita sejarah, ilustrasi, dan catatan dari masa lalu, menginterpretasikan catatan sejarah, dan membangun suatu cerita berdasarkan pemahamannya.

Dengan memiliki keterampilan berpikir historis, sduah pasti peserta didik dapat melakukan berpikir kritis dalam mengadapi suatu masalah. 
Untuk meningkatkan berpikir kritis peserta didik, dibutuhkan penerapan model pembelajaran sejarah. Kemampuan berpikir kritis dan menerakan model pembelajaran dibutuhkan sebagai prasyarat untuk memenuhi pembelajaran sejarah kritis sehingga peserta didik mampu mengambil sikap bijak dalam menghadapi permasalahan dalam pembelajaran sejarah.

\section{Daftar Pustaka}

Anis, M. Z. A. (2015). Sejarah Bukan Warisan Melainkan Pembelajaran.

Anis, M. Z. A., \& Wiyanarti, E. HISTORICAL LEARNING THROUGH THE HISTORICAL THINKING LEARNING MODEL (MPBH) BASED ON ISSUE CENTERED HISTORY BRINGS STUDENTS CAN THINK CRITICAL THINKING REALITY AND EXPECTATIONS. Jurnal Socius, 10(1), 1-11.

Anis, M. Z. A., Putro, H. P. N., Susanto, H., \& Hastuti, K. P. (2020). Historical Thinking Model in Achieving Cognitive Dimension of Indonesian History Learning. PalArch's Journal of Archaeology of Egypt/Egyptology, 17(7), 7894-7906.

Anis, M. Z. A., Sriwati, S., \& Mardiani, F. SISI ABU-ABU KAUSALITAS DAN EVALUASINYA DALAM PEMBELAJARAN SEJARAH. Jurnal Socius, 9(2), 169180.

Hudaidah. Historical Thinking, Keterampilan Berpikir Utama Bagi Mahasiswa Sejarah. FKIP Universitas Sriwijaya. p: 6-10.

Kamarga, H. (2017). Pengembangan social \& academic skills melalui model social inquiri dalam interaksi belajar-mengajar sejarah. Diakses dari: http://sejarah. upi. edu/artikel/dosen/pengembangan-socialacademic-skills-melalui-model-socialinquirydalam-interaksi-belajarmengajar-sejarah.

Nurjanah, W. Historical Thinking Skills and Critical Thinking Skills. HISTORIKA, 23(1), 92104.

Ofianto, O. (2017). Model Learning Continuum Keterampilan Berpikir Historis (Historical Thingking) Pembelajaran Sejarah SMA. Diakronika,17(2), 168-204.

Putro, H. P. N. (2012). Model Pembelajaran Sejarah Untuk Meningkatkan Kesadaran Sejarah Melalui Pendekatan Inkuiri. Paramita: Historical Studies Journal, 22(2).

Rohani, S., \& Sumantri, Y. K. UPAYA MENINGKATKAN KEMAMPUAN BERPIKIR KRITIS SISWA DALAM PEMBELAJARAN SEJARAH MELALUI STRATEGI GO TO YOUR POST. FACTUM: Jurnal Sejarah dan Pendidikan Sejarah, 9(1), 51-60. 
Zed, M. (2018). Tentang konsep berfikir sejarah. Lensa Budaya: Jurnal Ilmiah Ilmu-Ilmu Budaya, 13(1). 